karşısında yapıldığını savunması oldukça dikkat çekicidir. Bu açıdan eserin, Tevrat'ın bu olayı kurgulamasına karşı oldukça derinlikli bir eleştiri barındırdığını söylemek gerekmektedir.

Sâmirî ve yaptığı buzağıyla ilgili kapalı kalmış konuları Yahudi ve Mısır kaynaklarından yararlanarak yorumlamayı amaç edinen bir eser olması itibarıyla Sâmirî̀nin Buzağısı kitabı, Sina Dağı eteklerinde İsrailoğullarının buzağı yapma günahını yeniden yorumlamada oldukça başarılı bir eserdir. Yazar, yeni yorumlarını afaki olmaktan beri kılmak için birincil kaynaklara inmeye ve teşbihte hata olmazsa bir bulmacayı tamamlarcasında bu yorumların bütüne ilişkin anlamlı bir parça olması için büyük bir özen göstermiştir. Sonuç olarak Kur'an'ın tartışmalı konularından birini her ayrıntısıyla ele alan Sâmirî́nin Buzağısı kitabının, Kutsal kitaplarda yer alan kıssaları karşılaştırmalı olarak inceleme ve kıssaların özgün hallerini tespit etme konusunda yöntemsel ipuçları edinmek isteyenlerin okuması gereken faydalı bir eser olduğu kanaatindeyiz.

Dr. Tolga Savaş ALTINEL

Ekrem Sarıkçığlu, Kanonik-Apokrif İncillere Göre Hz. İsa Hayatı ve Mesajı, (Ankara: Ankara Okulu Yayınları, 2017), 248 s.

İnsanlık tarihinde krallar, bilim adamları, kahramanlar, komutanlar, din kurucuları ve daha sayamadığımız birçok ünlü sima gelip geçmiştir. Şüphesiz bunlar arasında gerek yaşadıkları dönem içerisinde gerekse kendilerinden sonra devasa kitleleri etkileyen kişilerden söz edilebilir. Bahsettiğimiz bu kimseler, din kurucularından başkaları değildir. Her ne kadar din kurucularının bir kısmı zamanla unutulup gitse de bazıları, müntesipleri giderek artan bir 
inanç sistemini arkalarından miras bırakmışlardır. Söz gelimi Hz. İsa bu şahsiyetlerin başında gelmektedir.

Türkiye'de Dinler Tarihi'nin gelişiminde yadsınamaz katkısı olan ve bu alanda söz sahibi birçok akademisyenin yetişmesinde etkin rol alan Ekrem Sarıkçıŏlu, eserinde Hz. İsa'nın hayatını tebliğ ve mesajinı konu edinmektedir. Şüphesiz Hz. İsa, tarihin gördüğü en önemli din kurucularından birisi olarak karşımızda çıkmaktadır. Öyle ki Hıristiyan düşüncesinin merkezi figürü olarak onun hakkında sayısız çalışma kaleme alınmıştır. Bu yazma faaliyeti hız kesmeden sürüp gitmektedir. Yazılan her bir eser ve yapılan her bir çalı̧̧ma birbirinden farklı İsa portreleri ortaya koymaktadır. Bu çalışmalardan kimisi çeşitli Hristiyan mezheplerinin görüşlerini içerirken kimisi de Hristiyan olmayanların kendine has görüşlerini içermektedir. Müellife göre ülkemizde Hz. İsa hakkında yazılan eserler genel itibariyle Kur' an ve hadis rivayetleri ışığında İslam bilginlerinin Hz. İsa hakkındaki görüşlerini içermektedir. Bununla beraber dinler tarihi alanındaki akademisyenlerin Hz. İsa ve Hristiyanlık hakkında telif ettiği çeşitli eserler de mevcuttur. Bunlara birkaç örnek zikredecek olursak Mahmut Aydın'a ait olan “Hz. İsa'ya Ne Oldu?", Hakan Olgun'a ait olan “Tuz ve Işık: Hz. İsa'nın Dağ Vaazı" gibi Dinler tarihçilerinin ve İslam âlimlerinin yazmış olduğu eserlerde İncillerden çeşitli misaller verilmektedir. Verilen bu misaller ise genel itibariyle kilisenin doğru saydığı ve 2. yüzyıl ile 5 . yüzyıl arasında kanonlaştırılan Yeni Ahit metinlerine dayanır.

Sarıkçıŏlu'nun tanıtmaya çalıştığımız bu son çalışmasında günümüze ulaşan gerek kanonik/gerçek gerekse apokrif/sahte kabul edilen İncillerdeki rivayetler ışı̆̆ında Hz. İsa'nın hayatını ve peygamberliğini ortaya koymaya çalışmaktadır. Fakat burada belirtmemiz gereken bir husus bulunmaktadır. Hz. İsa hakkında ne kendi döneminde ne de hemen sonrasında oldukça kısa şekilde $\mathrm{Hz}$. İsa'dan bahseden bazı kayıtların dışında O'nu uzun uzadıya ele alan kaynaklara rastlanmamaktadır. Fakat bu nakillerdeki bilgiler ise bir insan olarak Hz. İsa'nın hayatını ortaya koymaya yetecek kadar elverişli değildir. Dolayısıyla mevcut kaynaklar ve İncillerde bahsedildiği kadarıyla Hz. İsa'nın hayatından söz etmek oldukça zor bir mevzu olarak belirmektedir. Nitekim Sarıkçıŏ̆lu' nun eserini okurken bu durumu göz önünde bulundurmamız faydamıza olacaktır.

Eser ile ilgili konu başlıklarına bakacak olursak yazar, konuyu giriş ve üç bölüm altında ele almaktadır. Öncelikle giriş kısmında 
Hz. İsa'nın öncülleri olarak görülen Hz. Zekeriya ve Hz. Yahya'yı kısaca zikretmektedir. Nitekim Sarıkçıoğlu'nun Hz. İsa'dan önce Hz. Zekeriya ve Hz. Yahya'dan bahsetmesi, İsa ile olan ilişkileri sebebiyledir. Çünkü çocuğu olmayan ve karısı kısır olan birinin çocuğu olması ve bu çocuğa daha önce verilmeyen bir ismin verilmesi $\mathrm{Hz}$. İsa'nın gelişini hazırlamaktır. Dolayısıyla Hz. İsa'dan hemen önce müellifin konuya buradan başlaması gayet makuldür. Birinci bölümde yazar, “Hz. İsa'nın Hayatı" ana başlı̆̆ıyla Hz. İsa'nın doğumunu, hayatını ve çarmıha gerilmesine kadar olan dönemle ilgili rivayetleri ve ilgili İncil metinlerini esere konu edinmektedir. İkinci bölümde ise "Tebliğ ve Mesajları" ana başlığı altında yazar, Hz. İsa'nın vaaz ve nasihatlerinden hareketle onun gerçek mesajını ortaya koymaya çalışmaktadır. "Vefat Sonrası Gelişmeler" isimli üçüncü ve son başlıkta ise Hz. İsa'nın vefatı sonrası gelişmeleri dikkate alarak Hz. İsa sonrası gelişen teolojileri ya da sorunlu hususları ilk iki bölümde olduğu gibi Kanonik ve Apokrif İncil kayıtları üzerinden incelemektedir.

Yazar, giriş kısmında dönemin Mesih beklentilerini açıklayarak mevcut yapıyı ve dönemin kurtarıcı anlayışına temas etmektedir. Buna göre, Davud soyundan bir hükümdarın gelecek ve ebedi barışı yeryüzüne hâkim kılacaktı. Müellif, Yahudi kaynaklarına göre bu hakimiyetin İsrail topraklarından başlayarak diğer milletleri de içine alan adil bir idare olduğunu vurgulamaktadır. Bununla birlikte dünyevi olan bu hakimiyetin yanında tanrı hükümdarlığının yeniden diriliş sonrasında olacağına dair bir başka beklenti de mevcuttur. Bu beklentinin ahiret hayatına dönük olduğu yazar tarafından zikredilmektedir. İsa'nın hükümranlık tasavvurunun ise bu iki anlayışı da içerdiği, dolayısıyla mevcut beklentilere uygun olduğu öngörülmektedir (s. 15-17). Ayrıca yazar giriş kısmında konunun anlaşılması açısından Hz. Zekeriya'nın Hz. Meryem ile olan ilişkisine; aynı şekilde Hz. Yahya'nın Hz. İsa ile olan ilişkisine kısaca değinmektedir.

Birinci bölümde Hz. İsa'nın hayatını ele alan müellif doğal olarak Hz. İsa'nın annesi Hz. Meryem'le başlamaktadır. Hz. Meryem ile ilgili rivayetler genel olarak apokrif sayılan Yakup İncili etrafında irdelenmektedir. Hz. Meryem'in doğumu, mabede verilişi ve ergenliğe kadar geçen zamanı zikrederken Sarıkçığlu, Hz. Meryem ile ilgili bir soruna dikkat çekmektedir. Buna göre Hz. Meryem'in babası Yoahim bir gün mabette kurban sunmak için ön sıraya durur 
ve oradan bazı kimseler ona zürriyeti olmadığı için ön sırada durmaya hakkı olmadığını söylerler. Bu duruma üzülen Yoahim, inzivaya çekilir. Karısı Hanna da kocasının durumuna çok üzülerek Tanrı'ya yalvarır ve bir çocuğu olursa onu Tanrı'nın mabedine adayacağına dair bir söz verir. Tanrı Hanna'nın duasını kabul ederek ona bir evlat olarak Hz. Meryem'i verir. Hanna da sözünü tutarak onu mabede bağışlar. Buna göre Hz. Meryem 12 yaşına ayak basınca mabette bulunan rahipler kendi aralarında Meryem'e ne olacağıyla ilgili olarak istişare ederek Hz. Zekeriya'ya durumu iletip Rabbe dua etmesini isterler. Rabbe dua eden Hz. Zekeriya, Hz. Meryem'in birisi ile evleneceğini duyurmak için tüm dul erkeklere haber salar ve her bir erkeğe asa taşımasını söyler. Buna göre bu erkeklerden birine bir mucize verilecek ve mucize sahibi Meryem'i kendisine eş olarak alacaktır. Böylece mucize sahibi olan erkek Yakup ve Elişabe'nin marangoz oğlu Yusuf'tur. Kaynaklara göre Meryem, Yusuf'a zevce olarak verilmekte ve nişanlanmaktadır. Nişanlanan Meryem, Yusuf'un evine taşınmaktadır. Müellif, nişanlı Meryem ve Yusuf'un nikahları kiyılıncaya kadar neden Yusuf'un evinde kalmaya devam ettiğini veya nişandan sonra nikah hususunun İncillerde bahse konu edilmeyişini bir sorun olarak görür. Çünkü nişan yapıldıktan sonra İncillerde Meryem'in çocuklarından bahsedilmektedir. Fakat hiçbir şekilde nişandan sonra bir nikah olayı mevzu bahis olmaz. Nikah olayından hiç söz edilmemesi noktasında yazar, Hz. Meryem'in Hz. İsa'ya nikah öncesinde Kutsal Ruh'tan hamile kalmasından ve Tanrı Annesi/Theotokos olmasını sağlayan teolojik düşünceden kaynaklandığ1 düşünmektedir (s. 29-32). Birinci bölümün diğer kısımlarında ise Hz. İsa'nın çocukluğundan, vaftizi ve tarih sahnesine çıkışından apokrif ve Kanonik İncillerdeki bölümlere karşılaştırmalı olarak temas edilmektedir.

Müellif, ikinci bölümde Hz. İsa'nın tebliğinden ve mesajlarından bahsetmektedir. Bu bölümde, Hristiyanlık olarak kilisenin dogmatik görüşlerini bir kenara birakarak İncil rivayetleri üzerinden hareket etmektedir. Ona göre özetle İsa'nın vaaz ve nasihatlerindeki gerçek mesajı ortaya koymak için bu yönteme ihtiyaç vardır. Hz. İsa'nın ne yapmak istediğini kendi söz ve davranışlarından açıklamaya çalışmaktadır. Sarıkçıŏlu, kilise için asıl önemli olan Hz. İsa'nın ölümden dirildiği ve Tanrı oğlu olarak kabul edildiğine dair rivayetleri bir kenara bırakarak sadece bize ulaşan İncillerdeki rivayetler ile onun gündelik hayatına ışık tutmaya çalışmaktadır. Yazar, tüm bu kıstaslar bağlamında Hz. İsa'nın tebliğindeki amacı ihlas ve 
takva olarak zikretmektedir. Nitekim İsa, vaazlarında ve rahipleri tenkitlerinde şekilsel dindarlık yerine samimi dindarlık, ahlak ve merhamet üzerinde durmaktadır (s. 131-132).

Üçüncü ve son bölümde müellif, Hz. İsa'nın vefatı sonrasındaki gelişmeleri çeşitli başlıklar altında ele almaktadır. Bu başlıklarda öncelikle Hz. İsa'nın öldükten sonra yeniden dirilmesi rivayetlerinden başlayarak, vahdetten teslise dönüşen ve Hz. İsa'nın Tanrı Oğlu olarak anıldığı bir teolojiye doğru giden süreci kronolojik bir sırayla zikretmektedir. Bu sırayı takip ederken de Kudüs merkezli bir hareketin Roma merkezli bir harekete dönüşmesini kısa bir şekilde özetlemektedir. Ayrıca bu bölümde konunun dışında bir başlık olarak İncillerin nasıl meydana getirildiğini bir fikir oluşturması açısından çok kısa bir şekilde zikretmektedir (s. 241-243).

Bu eser, Hz. İsa'nın efsanelere karışmış ve çok kısa süren peygamberlik hayatını İnciller üzerinden müşahhas bir şekilde inşa etmeye çalışmaktadır. Buna göre hakkında çok fazla malumat bulunmayan bir insanın hayatını kısıtlı bilgiler ile ortaya koymak oldukça zordur. Mevcut bilgiler de kilisenin kanonik kabul ettiği Yeni Ahit metinlerine dayanır. Ayrıca dört İncil dışındaki metinleri de göz önüne alarak Hz. İsa'nın hayatından bahseden ayrıntılı bir eser henüz yayınlanmış değildir. Dolayısıyla bu eser, günümüze ulaşabilen tüm İncil rivayetlerini dikkate alarak Hz. İsa'nın hayatını ve tebliğini ortaya koymaktadır. Yazarın da önsözde belirttiği gibi bu eser, inanan ve inanmayan okuyucuların şu anda bilinen tüm İncillerden haberdar olmaları için kaleme alınmıştır. Sarıkçıŏlu'na göre Müslümanların ve Hristiyanların kendilerine has bakış açıları ve yaklaşımları malumdur. Buna rağmen Müslüman okuyucuların karşılaştırma yapması ve onlara yardımcı olmasını sağlamak için konuya ilişkin Kur'an ayetleri dipnotlarda verilmektedir.

Müellifin İncil kayıtları noktasında dikkat edilmesi gereken bir tasarrufu da vardır. Sarıkçıŏlu, İncillerde Hz. İsa hakkında yazarın bahsetmediği bazı pasajlar da mevcuttur. Bu pasajlar genelde İncil yazarlarının yorumlarıdır. Ancak müellif, yalnızca Hz. İsa'nın ağzından doğrudan doğruya çıan rivayetlere yer vermesi sebebiyle bu pasajları zikretmemektedir. Dolayısıyla Hz. İsa'nın söylediklerine ters düşen kayıtlara eserde yer verilmemektedir. Diğer bir önemli nokta ise kilisenin teolojik savunma için İncillere sonradan dâhil ettiği veya Hz. İsa hakkındaki efsanevi bazı rivayetlerden bahsedilmemesini daha doğru bulan yazar, yine de okuyucuyu bilgi- 
lendirme amaciyla, Hz. İsa'nın yeniden dirildikten sonra cehenneme inip Hades ile görüşmesi gibi efsanevi kimi anlatılara yer vermiştir (s. 204-210).

Eserin bu olumlu yönlerinin yanı sıra eserde bir başlığın daha olması gerekirdi. Buna göre Hristiyan bir birey açısından bir İncil'in ne anlam ifade ettiği, Kanonik İncillerin neden dört tane olduğu, İncillerin vahiy ürünü olup olmadığı eğer vahiy ürünü iseler bunların neden farklı insanlar tarafından yazıldığ 1 ve birbirlerinden neden bu kadar farklı oldukları hususlarını genel olarak sunan bir başlık daha olabilirdi. Zira bu husus, Türkiye'de genel okuyucu kitlesi ve özelde konuya ilişkin çalışma yapmayı hedefleyen lisans ve lisansüstü öğrencileri için bir ihtiyaç olarak belirmektedir. Bu eseri, Hz. İsa'nın hayatını merak eden hem Hristiyanlar hem de konuya ilgi duyan Müslümanlar için öneriyoruz. Türkçe kaynaklar arasında Hz. İsa'nın insan olarak doğumundan, ölümüne ve sonrasında gelişen olayların tamamını Apokrif ve Kanonik İnciller bağlamında zikreden tek kaynak niteliğindeki bu eser, konuya ilişkin araştırma yapanlar için bir başvuru kaynağı mesabesindedir.

Muhammet Hanifi BAKIŞGAN Yüksek Lisans Öğrencisi, Mardin Artuklu Üniversitesi, Felsefe ve Din Bilimleri

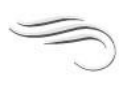

\section{Mehmet Alıcı, Işığın Elçisi Mani ve Gnostik Düşüncesi,}

(Divan Kitap, İstanbul, 2018), $422 \mathrm{~s}$.

İnsanın kurtuluşunu hedefleyen dinlerin temel öğretilerini belirleyen etmenlerin başında insanın madde ile olan ilişkisine yönelik konular gelmektedir. Kimi dini gelenekler insanı bir bütün olarak ele alırken, kimileri de maddeyi teolojik ve ontolojik açıdan kötü olarak 